\title{
Three new hypogean species of the false scorpions genus Ephippiocbthonius Beier, 1930 (Arachnida: Pseudoscorpiones: Chthoniidae) from the Crimean Peninsula
}

\author{
Три новых гипогейных вида можноскорпионов рода \\ Ephippiochthonius Beier, 1930 (Arachnida: Pseudoscorpiones: \\ Chthoniidae) с Крымского полуострова
}

\author{
I.S. Turbanov ${ }^{1,2}$, V.B. Kolesnikov ${ }^{3}$ \\ И.С. Турбанов ${ }^{1,2}$, В.Б. Колесников ${ }^{3}$
}

\begin{abstract}
${ }^{1}$ I.D. Papanin Institute of Biology of Inland Waters of Russian Academy of Sciences, Borok, Yaroslavl Region, 152742, Russia. E-mail: turba13@mail.ru

${ }^{1}$ Институт биологии внутренних вод им. И.Д. Папанина РАН, Борок, Ярославская обл., 152742, Россия.

${ }^{2}$ Cherepovets State University, Cherepovets, Vologda Region, 162600, Russia.

2 Череповецкий государственный университет, Череповец, Вологодская обл., 162600, Россия.

${ }^{3}$ Federal public budgetary scientific institution All-Russian Research Institute of Protection of Plants, Voronezh Region, 396030, Russia. E-mail: jukoman@yandex.ru

${ }^{3}$ Федеральное государственное бюджетное научное учреждение “Всероссийский научно-исследовательский институт защиты растений”, Воронежская обл., 396030, Россия.
\end{abstract}

KEY WORDS: Arachnida, new species, taxonomy, false scorpions, cave, troglomorphic species, neotroglobiont.

КЛЮЧЕВЫЕ СЛОВА: Arachnida, новый вид, таксономия, ложные скорпионы, пещера, трогломорфный вид, неотроглобионт.

ABSTRACT. Three new hypogean species of the false scorpions genus Ephippiochthonius Beier, 1930 from the caves of the Crimean Peninsula, i.e. E. tauroscythicus sp.n., E. volkeri sp.n. and E. pliginskyi sp.n. are described. Diagnostic and ecological features of these species are presented and discussed, as well as compared with the related species of this genus. A hypothesis about a possible scenario of speciation of troglomorphic species of the genus Ephippiochthonius in the caves of the Crimean Mountains in connection with global climate changes is proposed.

How to cite this paper: Turbanov I.S., Kolesnikov V.B. 2021. Three new hypogean species of the false scorpions genus Ephippiochthonius Beier, 1930 (Arachnida: Pseudoscorpiones: Chthoniidae) from the Crimean Peninsula // Arthropoda Selecta. Vol.30. No.2. P.193-204. doi: 10.15298/arthsel.30.2.06

РЕЗЮМЕ. Описывается три новых гипогейных вида ложных скорпионов рода Ephippiochthonius Beier, 1930 из пещер Крымского полуострова E. tauroscythicus sp.n., E. volkeri sp.n. и E. pliginskyi sp.n. Приводятся и обсуждаются диагностические и экологические особенности этих видов, а также сравниваются с близкими видами этого рода. Высказывается гипотеза о возможном сценарии видообразования трогломорфных видов рода Ephippio- chthonius в пещерах Горного Крыма в связи с глобальными климатическими изменениями.

\section{Introduction}

The fauna of false scorpions of the Crimean Peninsula has been poorly studied, moreover the available studies are represented by a small number of taxonomic [Redikorzev, 1918; Lebedev, 1927; Čurčić, 1984; Zaragoza, 2010; Kolesnikov, Turbanov, 2017, 2018; Turbanov, Kolesnikov, 2020] and faunistic [Lebedinsky, 1904; Ellingsen, 1910; Lebedev, 1914; Pliginsky 1927; Chamberlin, 1949; Schawaller, 1989; Dashdamirov, 1999; Turbanov, Kolesnikov, 2015] publications. The above mentioned publications do not represent the true diversity of false scorpions of the Crimea, a region of the Eastern Mediterranean with a rich biodiversity. However, during the study of the cave biota of the Crimea, we found a number of false scorpions species that belong to the family Chthoniidae Daday, 1888 and identified them as representatives of the genus Ephippiochthonius Beier, 1930.

Recently the genus Ephippiochthonius was erected as a valid taxon by Zaragoza [2017]. The genus is widely distributed across the Mediterranean and Macaronesian region, reaching Iran to the east, and Scandinavia to the north. There are records of this genus from other parts of the world (North and South America, 


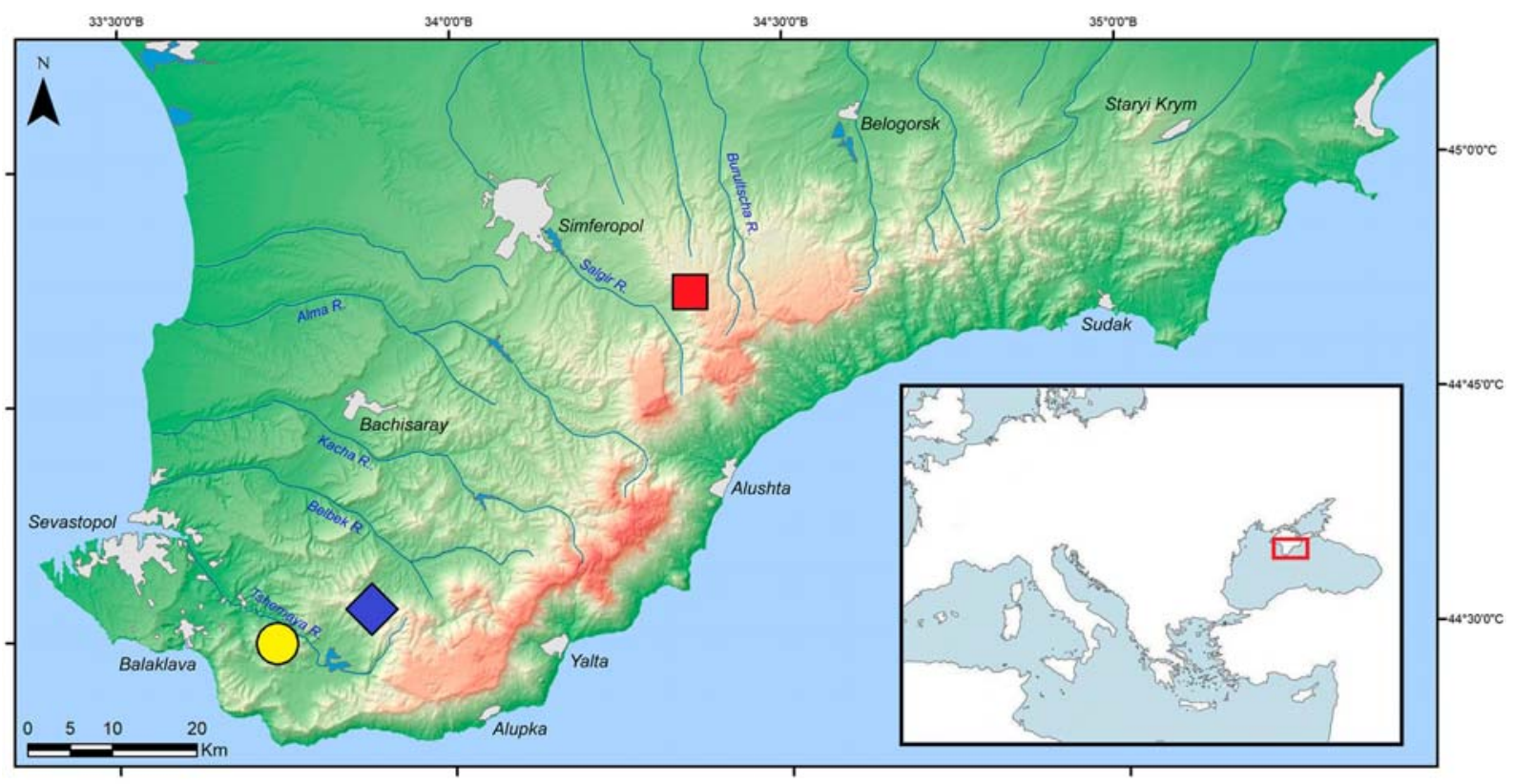

Fig. 1. Map of collection sites (caves) for the three species of the genus Ephippiochthonius in the Crimean Mountains: E. tauroscythicus sp.n. (yellow circle) — Tshernoretshenskaya Cave; E. volkeri sp.n. (blue diamond) — Syundyurlyu-Kobasy (= Syundyurlyu) Cave; E. pliginskyi sp.n. (green square) - Kizil-Koba (= Krasnaya) Cave.

Рис. 1. Карта мест сбора (пещеры) для трех видов рода Ephippiochthonius в Горном Крыму: E. tauroscythicus sp.n. (желтый круг) - пещера Чернореченская; E. volkeri sp.n. (синий ромб) — пещера Сюндюрлю-Кобасы (=Сюндюрлю); E. pliginskyi sp.n. (зеленый квадрат) — пещера Кизил-Коба (= Красная).

Hawaii, Cuba, Seychelles, and southwestern Australia). Gardini [2013] revised the Italian species of this genus; Zaragoza [2017] revised the species of this genus in the Iberian Peninsula, the Balearic Islands and Macaronesia. In the Eastern Mediterranean regions located near the Crimea, representatives of the genus Ephippiochthonius are known from the Caucasus and adjacent regions [Schawaller, 1983; Schawaller, Dashdamirov, 1988; Kolesnikov et al., 2019; Nassirkhani et al., 2019].

For the Crimean Peninsula, for the first time, representatives of the genus Ephippiochthonius are quoted by Lebedinsky [1904] as Obisium abeillei (Simon, 1872) (= Neobisium (Blothrus) abeillei (Simon, 1872) in the modern representation) from Kizil-Koba (= Krasnaya) Cave. Later, Pliginsky [1927] collected E. tetrachelatus (Preyssler, 1790) in the same cave, showed referring to the definition and opinion of V.V. Redikorzev, that the identified and illustrated by Lebedinsky [1904] O. abeillei should be classified as E. tetrachelatus. Moreover, Ellingsen [1910] points to the presence of E. tetrachelatus in the terrestrial biotopes the region of Alushta.

However, the above given indications of the widespread E. tetrachelatus in the Crimea are likely to be wrong and could be in fact a group of species [Dashdamirov, Schawaller, 1993; Gardini, 2013; Zaragoza, 2017; Kolesnikov et al., 2019], which is partly confirmed by this study.

Three new hypogean species false scorpions of the genus Ephippiochthonius from the Crimean Peninsula are described and illustrated in this paper.

\section{Materials and methods}

SAMPLING AND REPOSITORIES. Totally, six specimens of the described three new species of the genus Ephippiochthonius from three caves of the Crimean Mountains have been studied (Fig. 1), a part of which was collected by the first author: two specimens of E. tauroscythicus sp.n. from Tshernoretshenskaya Cave (Baydarsko-Balaklavsky Karst Massif), and three specimens of E. volkeri sp.n. from Syundyurlyu-Kobasy (= Syundyurlyu) Cave (Ai-Petri Karst Massif); and also one specimen of E. pliginskyi sp.n. from Kizil-Koba (= Krasnaya) Cave (Dolgorukovsky Karst Massif) described in Pliginsky [1927] article as E. tetrachelatus and stored at the ZISP. Cave biotopes, inhabited by the described new species of the genus Ephippiochthonius, are presented in Fig. 2.

The type material is deposited in the Zoological Museum of Moscow University (ZMUM), Zoological Institute of the Russian Academy of Sciences, Saint Petersburg (ZISP), and the private collections of I. Turbanov (IT).

MORPHOLOGICAL CHARACTERS AND TERMINOLOGY. All pseudoscorpions collected were fixed in a $96 \%$ ethyl alcohol. For morphological examination under a light microscope, they were cleaned in pure lactic acid and temporarily mounted on microscopic slides. Some specimens were dissected for a more detailed study of the chelicerae and pedipalps. All drawings were made from microscope preparations using an RA-4 camera lucida attached to a Biomed 6 variant 3 microscope. After the study, each sample, together with dissected body parts, was returned to a tube containing $96 \%$ ethanol.

The measurements were taken with an ocular micrometer using the reference points proposed by Chamberlin [1931] and expressed in millimeters, followed by standard ratios in 

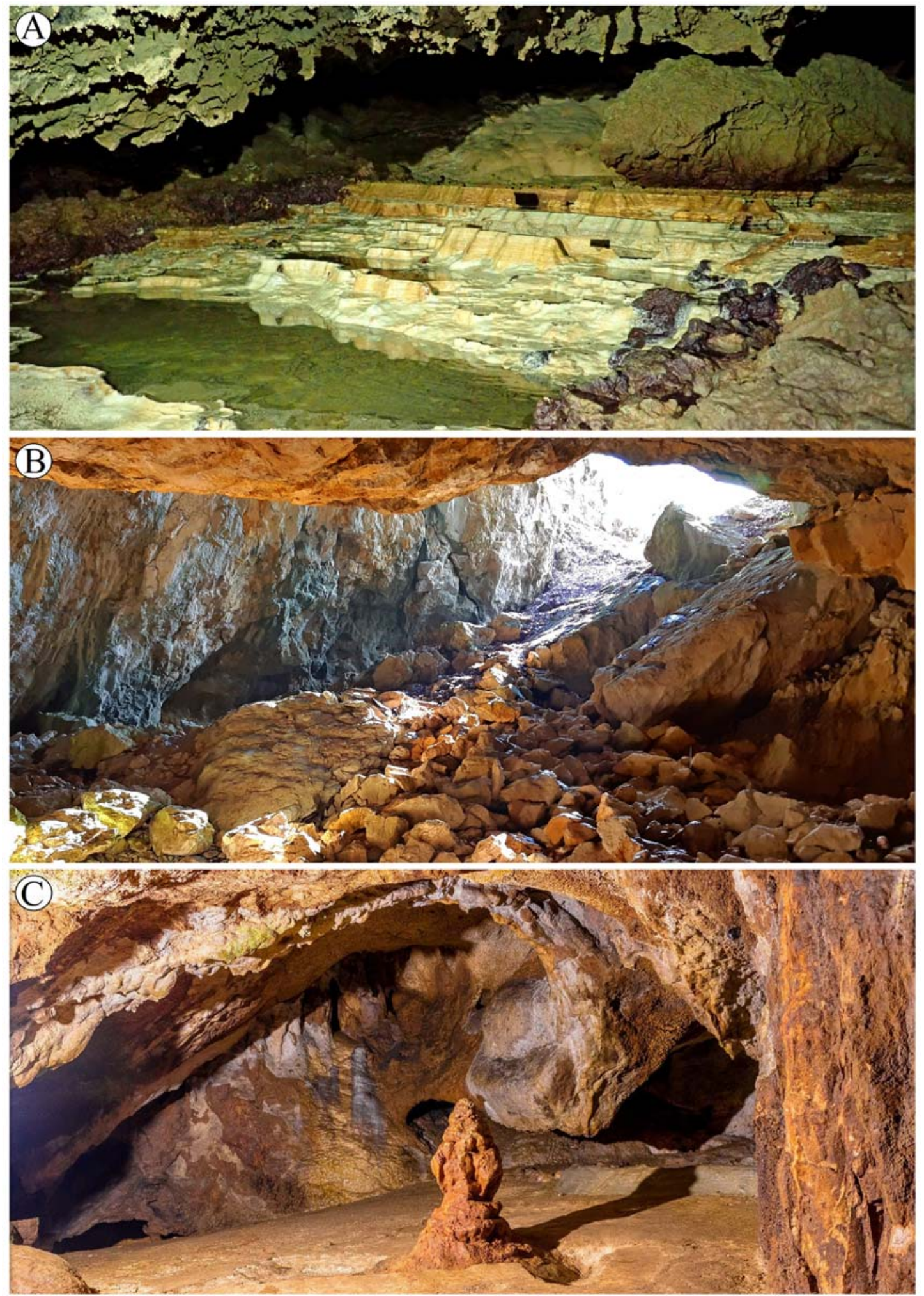

Fig. 2. Cave biotopes inhabited by the described new species of the genus Ephippiochthonius: A - Tshernoretshenskaya Cave, biotope E. tauroscythicus sp.n. (photo by I.S. Turbanov); B - Syundyurlyu-Kobasy (=Syundyurlyu) Cave, biotope E. volkeri sp.n. (photo by S.V. Arefyev); C - Kizil-Koba (= Krasnaya) Cave, biotope E. pliginskyi sp.n. (photo by S.N. Bagach).

Рис. 2. Пещерные биотопы, в которых обитают описываемые новые виды рода Ephippiochthonius: A - пещера Чернореченская, биотоп E. tauroscythicus sp. n. (фото И.С. Турбанова); В - пещера Сюндюрлю-Кобасы (=Сюндюрлю), биотоп E. volkeri sp.n. (фото С.В. Арефьева); С - пещера Кизил-Коба (= Красная), биотоп E. pliginskyi sp.n. (фото С.Н. Багача). 
parentheses. The ratios provided were: length to width for carapace, chelicerae and pedipalps, except in the case of the chela and its hand, for which the depth was used instead of width [Mahnert, 2011]. We applied terminology used by Chamberlin [1931], with amendments proposed by Harvey [1992], and Judson [2007]. The chaetotactic formulae of the carapace and chelicera are given according to Gabbutt \& Vachon [1963]. The terms "sublateral ocular seta" (osl), "lateral ocular seta" $(o l)$, "posterior dorsal row", "lateral row", "median row" and "anterior dorsal row" were used in accordance with the interpretation of Gabbutt \& Vachon's [1963] for the ocular row and femoral chaetotaxy. Tactile setae on tergites IX and XI and sternite X are frequently lost in preserved specimens. In such cases their tactile nature was determined by a larger diameter of the areolar insertion in comparison with other setae on the same segment and no measurement data were provided. Following Gardini [2013, 2014], measurements of the pedipalpal trochanter and of all parts of legs I and IV were excluded because they added too little meaningful information.

Abbreviations used in text and figures: af and am spot sensilla; al — anterolateral seta of carapace; ame anteromedial seta of carapace; as - antiaxial sensory setae; $c s$ - cheliceral spinneret; $d i$ - isolated subapical tooth of movable cheliceral finger; $d p s$ - distal marginal seta of pedipal; $e h$ - edge; $f a$-antiaxial lyrifissure of fixed chelal finger; $f b$ - basal lyrifissures of fixed chelal finger; $f d_{1}, f d_{2}$, $f d_{3}$ - dorsal lyrifissures of the fixed chelal finger; $h d-$ distal lyrifissure of chelal hand; $h p$ - proximal lyrifissure of chelal hand; ip - intercondylar protuberance; ldb, ldst, $l d t, l v b, l v t$ - lyrifissures associated with cheliceral setae $d b, d s t, d t, v b$ and $v t$, respectively; $m$ - microseta; $m a$, $m a_{2}$ - antiaxial lyrifissures of movable chelal finger; $o l-$ lateral ocular seta of carapace; om - medial ocular seta of carapace; osl - sublateral ocular seta of carapace; $p c$ coupled sensilla of movable chelal finger; $p l$ - posterolateral seta of carapace; $p m$ - posteromedial seta of carapace; $s p$ - subdistal protuberance; $\mathrm{T}$ - tactile seta; $t d$ - accessory tooth of movable cheliceral finger.

\section{Taxonomic part}

\section{Ephippiochthonius tauroscythicus sp.n.} Fig. 3.

HOLOTYPE 9 (ZMUM TI-61), Crimean Peninsula, region of Sevastopol, canyon of Tshernaya River, Tshernoretshenskaya Cave, 5 May 2017, leg. I.S. Turbanov.

PARATYPE: 1 (ZMUM TI-62), same cave and collector, together with holotype, 3 March 2018.

DISTRIBUTION. Known from the type locality so far.

NAME. Named after the Tauroscythians (ancient Greek

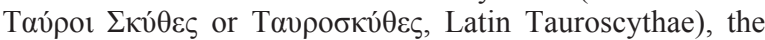
people who inhabited the Crimean Mountains from the end of the 3 rd century $\mathrm{BC}$ to the 4 th century AD.

DIAGNOSIS ( + , $\sigma^{7}$ unknown). A large hypogean Ephippiochthonius that differs from other species of the tetrachelatus-group in the following combination of characters: anterior eyes with convex lens, posterior eyes reduced to a smooth cuticular area; movable cheliceral finger without a small isolated subapical tooth $(d i)$; spinneret $(c s)$ present; carapace with a short epistome; lateral ocular setae, sublateral ocular setae and anterolateral setae approximately of equal length; posterolateral seta $(p l)$ of carapace absent; pedipalpal hand (lateral view) with weak depression at the level of $i b / i s b$ and an abrupt slope between trichobothria $i b /$ $i s b$ and $e b$; fixed and movable chelal fingers respectively with 23-24 and 8-9 triangular teeth; fixed chelal finger at level of est-it with 3 teeth occupying $0.1 \mathrm{~mm}$ (distance between successive apices $0.040-0.045 \mathrm{~mm}$ ); proximal half of movable chelal finger smooth, without dental canals; sensilla $p c$ well distad of $s b$; trichobothrium ist level with $e s b$ (esb slightly distal of ist) and well proximad of lyrifissure $f b$; length of chela $1.30-1.31 \mathrm{~mm}$, length of movable chelal finger $0.74-0.75 \mathrm{~mm}$; chela $5.20-5.69$ times as long as deep; ratio of pedipalpal femur/carapace 1.53-1.61.

Description of adults (,$+ \diamond^{7}$ unknown). Large, hypogean, moderately troglomorphic species. Integument depigmented; weakly hispid granulation on lateral surfaces of carapace, on cheliceral hand and on bases of chelal fingers.

Carapace not longer than broad and constricted posteriorly; anterior margin (Figs 3A-C) closely dentate between median macrosetae, with a weakly prominent epistome; ocular area as in Fig. 3A, anterior eyes with convex lens (diameter $0.050 \mathrm{~mm}$ ), posterior eyes reduced to a smooth cuticular area (diameter $0.030-0.032 \mathrm{~mm}$ ), all eyes with tapetum; distance from anterior eyes to anterior margin of carapace $0.050-0.055 \mathrm{~mm}$; distance between anterior and posterior eyes $0.079-0.085 \mathrm{~mm}$. Chaetotaxy: 18 macrosetae and 2 preocular microsetae $(m)$ (sometimes on one side there can only be 1 microseta) on each side, posterior row with 2 medial macrosetae $(\mathrm{pm})$, posterolateral seta $(p l)$ absent, macrosetae thin; setal formula: $\mathrm{mm} 4 \mathrm{~mm}: 6: 4: 2: 2$ (rarely $\mathrm{mm} 4 \mathrm{~m}: 6: 4: 2: 2$ ), anteromedial setae $0.16 \mathrm{~mm}$ long, anterolateral setae $0.13-0.15 \mathrm{~mm}$ long, sublateral ocular setae 0.12 $\mathrm{mm}$ long, lateral ocular setae $0.14-0.15 \mathrm{~mm}$ long; 4 lyrifissures anteriorly and 2 posteriorly.

Chaetotaxy of tergites: $4: 4: 4: 4: 6: 6: 6: 6: 1 \mathrm{~T} 2 \mathrm{~T} 1: 4: 1 \mathrm{~T} 2 \mathrm{~T} 1: 0$.

Chaetotaxy of sternites: 10:(3)8(3):(2)7-8(2):m6m:m5$6 \mathrm{~m}: \mathrm{m} 5 \mathrm{~m}: 6: 6: 2 \mathrm{~T} 1 \mathrm{~T} 2: 0: 2$, lateral setae on sternites III-VII microsetal in size, sternite $\mathrm{X}$ with 2 submedial tactile setae.

Chelicerae (Figs 3D-F) with 6 setae and 2 lateral microsetae; seta $v b 0.055-0.056 \mathrm{~mm}$ long, seta it $0.061-0.063$ $\mathrm{mm}$ long, seta $d b \quad 0.098-0.10 \mathrm{~mm}$ long, seta $d s t 0.20-0.23$ $\mathrm{mm}$ long, seta $d t 0.18 \mathrm{~mm}$ long, microsetae $0.020 \mathrm{~mm}$ long; all macrosetae are of the same thickness; hand with 5 dorsal and 1 ventral lyrifissure, lyrifissure $l d b$ present. Fixed finger with 9-10 teeth proximally reduced in size, three distal teeth larger; movable finger without an isolated subapical tooth $(d i)$, at the same level with the spinneret $(c s)$ there is only a very small tubercle (Fig. 3F), with 7 teeth decreasing in size proximally, the four distal one larger ratio seta $g l 0.56$; spinneret prominent and apically rounded; rallum with 1112 blades; serrulae interior and exterior respectively with 11 and 12 blades.

Coxal setae: pedipalpal coxa with 5 setae (including 2 on manducatory process), distal marginal seta of disk 0.15 mm long; coxa I $3+3$ marginal microsetae, distal marginal seta $0.09 \mathrm{~mm}$ long; II $4+12-16$ bipinnate coxal spines, III 4-5 + 6-7 bipinnate coxal spines and IV 6-7; intercoxal tubercle bisetose.

Pedipalp: femoral chaetotaxy $3: 6: 2: 5: 1$ (in holotype the right femur has a chaetotaxy $3: 6: 2: 6: 1$; in paratype the left femora has a chaetotaxy $3: 6: 3: 5: 1$ ). Chela (Figs 3G-J) with hand weakly depressed at level of $i b / i s b$ and an abrupt slope between trichobothria $i b / i s b$ and $e b$; intercondilar protuberance (ip) present; chaetotaxy 4:5:3; seta $p h_{3}$ absent, setae $i h_{l}$, $i h$ and $i h_{4}$ approximately level with trichobothria $i b / i s b$. Fixed chelal finger with 23-24 teeth, mostly pointed and with dental canals, decreasing in size proximally, 1 distal 

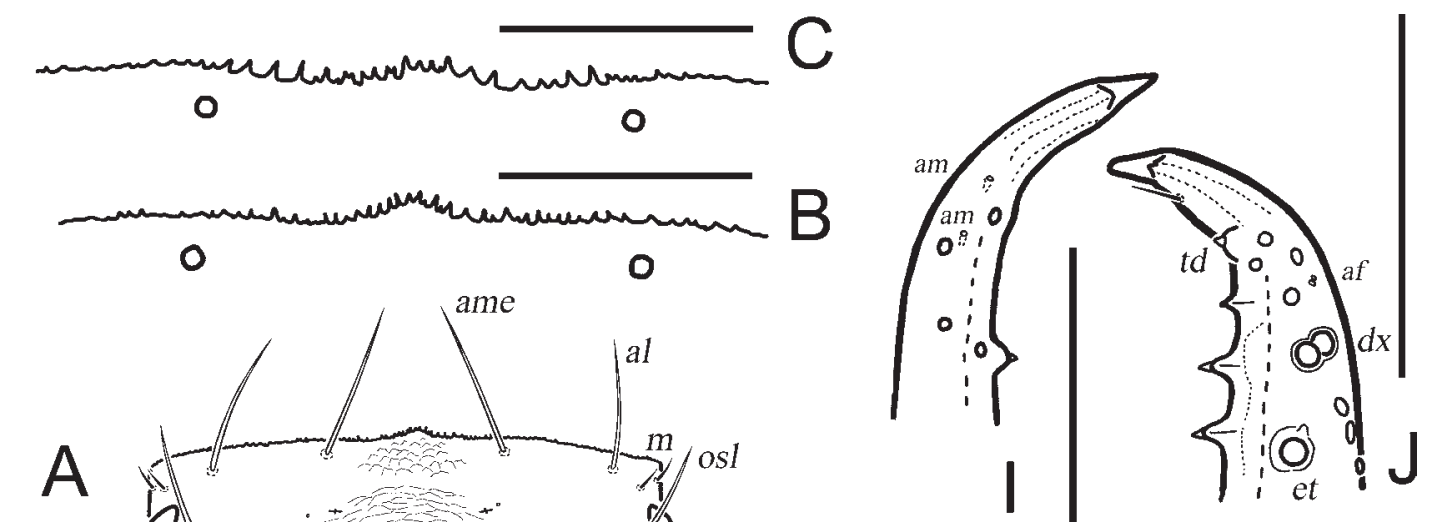

A
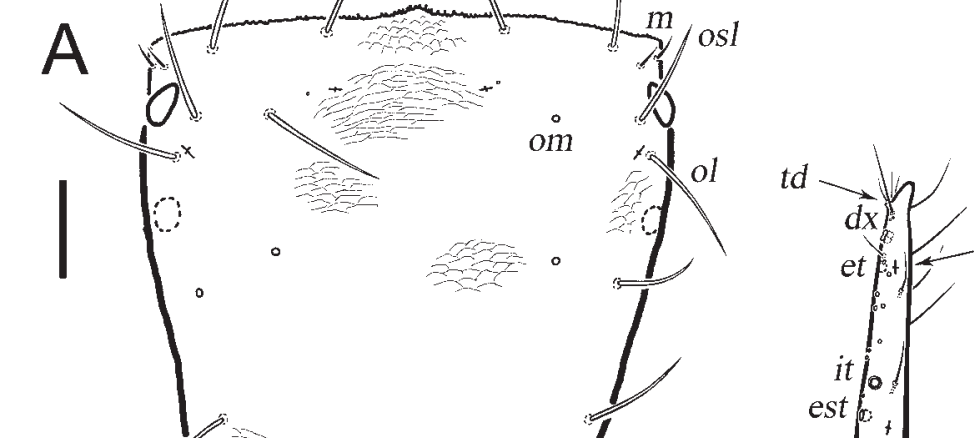

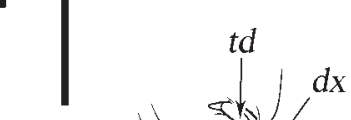
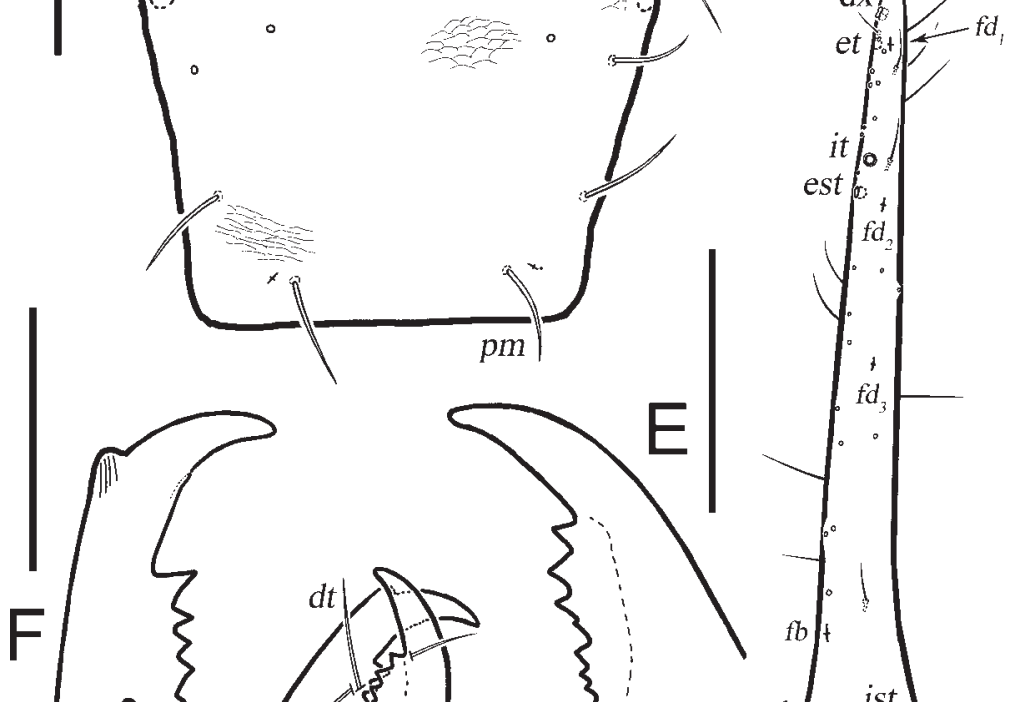

it
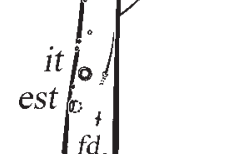

gl
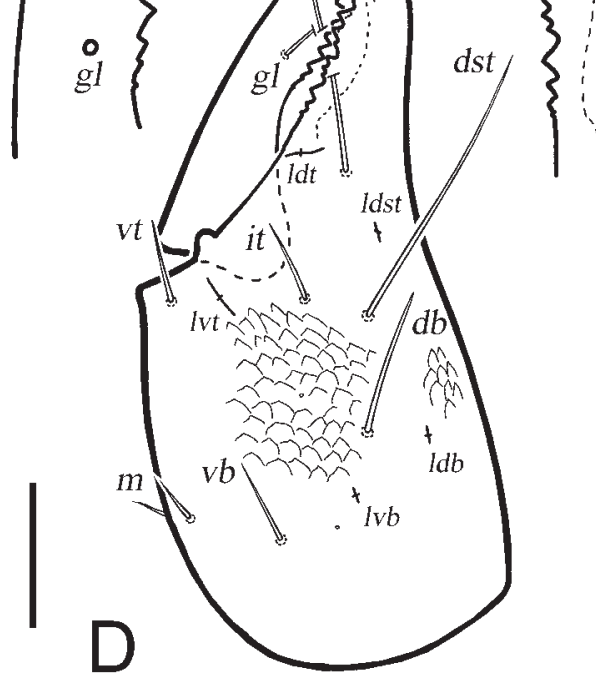

Fig. 3. Ephippiochthonius tauroscythicus sp.n. + holotype and paratype: A - holotype, carapace, dorsal view; B — holotype, anterior margin of carapace; C - paratype, anterior margin of carapace; D - holotype, left chelicera; E - holotype, fixed finger of left chelicera, partial view; F - holotype, movable finger of left chelicera, partial view; $\mathrm{G}$ - holotype, left chela, dorsal view; $\mathrm{H}$ - holotype, left chela, lateral view; I - holotype, distal part of movable finger of left chela; J - holotype, distal part of fixed finger of left chela. Scale bars: $0.1 \mathrm{~mm}$.

Рис. 3. Ephippiochthonius tauroscythicus sp.n. голотип и паратип: А — голотип, карапакс, вид сверху; В — голотип, передний край карапакса; C - паратип, передний край карапакса; D - голотип, левая хелицера; Е — голотип, неподвижный палец левой хелицеры, часть; F — голотип, подвижный палец левой хелицеры, часть; G — голотип, левая хела, вид сверху; Н — голотип, левая хела, вид сбоку; I — голотип, дистальная часть подвижного пальца левой хелы; J — голотип, дистальная часть неподвижного пальца левой хелы. Масштаб: 0,1 мм. 
tooth noticeably smaller than the second one, dental row almost reaching distad of trichobothrium $b$; base of fixed finger with 2-3 microtubercles; tip of fixed finger with a modified accessory tooth $(t d)$ on antiaxial face; one pair of long antiaxial sensory setae (as) at the finger base, distance between them longer than finger depth at base; fixed chelal finger at level of est-it with 3 teeth occupying $0.1 \mathrm{~mm}$ (distance between successive apices $0.040-0.045 \mathrm{~mm}$ ). Distal half of movable chelal finger with $8-9$ pointed teeth with dental canals, subdistal tooth absent, proximal half of dental lamina smooth, without dental canals, dental row reaching halfway between trichobothria $s t$ and $s b$; basal apodeme long and apically indented; coupled sensilla $p c$ well distad of $s b$. Trichobothria as in Figs $3 \mathrm{G}, \mathrm{H}$, trichobothrium ist level with esb (esb is slightly distal of $i s t)$ and well proximad of lyrifissures $f b$; distance between $s t$ and $s b 1.68$ times longer than that between $s b$ and $b$. Chelal lyrifissure patterns $h p, h d, f b, f a_{1} f d_{1}, f d_{2}, f d_{3}, m a_{1}, m a_{2}$ present.

Measurements and ratios. $q$ holotype ( $q$ paratype in square brackets): Body 1.97 [1.97]. Carapace 0.55/0.54 (1.01) [0.56/0.55 (1.01)]. Chelicera 0.52/0.27 (1.92) $[0.52 / 0.26$ (2.0)], movable finger 0.26 [0.26]. Pedipalp: femur $0.84 /$ 0.14 (6.0) [0.90/0.14 (6.42)], patella $0.32 / 0.15(2.13)[0.32 /$ $0.16(2.0)]$, chela $1.31 / 0.23(5.69)[1.30 / 0.25(5.20)]$, hand 0.57 [0.55], movable finger 0.74 [0.75]; ratio movable finger/hand 1.30 [1.36], femur/movable finger 1.14 [1.20], femur/carapace 1.53 [1.61], chela/carapace 2.38 [2.32], chela/femur 1.56 [1.44].

REMARKS. The new species is ascribed to the genus Ephippiochthonius on the basis of the following features: chela lagyniform (ephippiochthonian), seta $h p_{3}$ in the proximal portion of chelal hand absent, medial protuberance ( $i p$ ) present between chelal condyles. The new species belongs to the tetrachelatus-group as defined by Gardini [2013] and Zaragoza [2017] by having the the teeth of the fixed chelal finger present nearly to the base of the finger, the movable chelal finger with low, rounded, sometimes vestigial teeth, without a marginal lamina, intermediate paraxial setae hil, $h i 3$ and hi4 of chelal hand level with trichobothria $i b / i s b$, movable chelal finger with lyrifissure $m a 2$. Within the tetrachelatus-group, the new species is closest to E. concii Beier, 1953 from Italy: Liguria, Sicily, Sardinia; the Maltese Archipelago [Gardini, 2013] and E. pliginskyi sp.n. [this study]. It differs from E. concii in more troglomorphic features of the structure of chela, basal lamina of movable chelal finger smooth, the teeth of the movable chelal finger reach about the middle of the distance between $s b$-st, es $b$ located slightly in front of the ist, the distance between the anterior and posterior eyes is noticeably larger.

A number of features that characterize the new species such as coupled sensilla $p c$ well distad of $s b$, length of chela $1.30-1.31 \mathrm{~mm}$, ratio movable finger/hand 1.30-1.36; pedipalpal femur/movable finger 1.14-1.20, pedipalpal femur/ carapace 1.53-1.61 fall within the limits of the features defined by Gardini [2008, 2013] for E. concii from some caves in Sardinia. It is worth noting that "he emphasized that shortage of specimens from populations of isolated karstic systems, showing different degrees of troglomorphy, makes impossible a reliable valuation of their taxonomic status: Sardinian specimens from Nuxis are identical to those from western Liguria, whereas specimens from the caves of Armungia and Ulassai show different degrees of troglomorphic specialization (see Gardini [2008], table 2)", this means that it hides a complex of species.

In our opinion, the indicated features similar for E. tauroscythicus sp.n. and E. concii from caves in Sardinia are not sufficient grounds to consider them as one species. The presence of the above mentioned morphological differences between E. tauroscythicus sp.n. and E. concii, as well as their geographical distance of their ranges, indicate the independence of the described species.

E. tauroscythicus sp.n. differs from E. pliginskyi sp.n. in slightly larger size of chela and pedipalpal femur, larger ratios of pedipalpal femur/carapace and chela/carapace, a large number of teeth on the movable and fixed chelal fingers, a smaller distance between $s t$ and $s b$ relative to the distance between $\mathrm{sb}$ and $\mathrm{b}$, the location of ist relative to esb (esb is slightly distal of ist), the teeth of the movable chelal finger approximately reach the middle of the distance between $s b$-st, a large distance between sensory setae (as) relative to the depth of the fixed finger.

The new species is also notable for the variability in the pedipalpal femur chaetotaxy - one of them (but not both) may have an additional seta located either on the posterior dorsal row or on the lateral row. Median and anterior dorsal row have a constant number of seta, the ventral setae is also always one. The observed variability makes the pedipalpal femur chaetotaxy a conditional taxonomic feature at the species level. It is required a more detailed study of this variability based on more material.

\section{Ephippiochthonius volkeri sp.n.} Fig. 4.

HOLOTYPE $O^{7}$ (ZMUM TI-63) Crimean Peninsula, region of Sevastopol, Mt. Syundyurlyu-Kayasy, Syundyurlyu-Kobasy (= Syundyurlyu) Cave, 5 October 2016, leg. I.S. Turbanov.

PARATYPE: $1 \sigma^{7}$ (IT), 1 क (ZMUM TI-64), same cave, date and collector, together with holotype.

DISTRIBUTION. Known from the type locality so far.

NAME. Named after the late Dr. Volker Mahnert (19432018) - director of the Muséum d'Histoire naturelle, Geneva, arachnologist, entomologist and ichthyologist who helped the authors at the initial stage of the exploration and study of false scorpions.

DIAGNOSIS $\left(\mathrm{O}^{\top}+\right.$ ). A small epigean Ephippiochthonius that differs from other species of the tetrachelatusgroup in the following combination of characters: two pairs of eyes with lens; movable cheliceral finger without a small isolated subapical tooth $(d i)$; spinneret $(c s)$ present; carapace with a short epistome; lateral ocular setae 1.5 times longer than the sublateral ones and approximately equal in length to anterolateral setae; posterolateral seta $(p l)$ of carapace absent; pedipalpal hand (in lateral view) with weak depression at level of $i b / i s b$ and an abrupt slope between trichobothria $i b / i s b$ and $e b$; fixed and movable chelal fingers respectively with 14-17 and 5-6 triangular teeth; fixed chelal finger at level of est-it with 5-6 teeth occupying $0.1 \mathrm{~mm}$ (distance between successive apices $0.020-0.025 \mathrm{~mm}$ ); proximal half of movable chelal finger with 2-3 low vestigial teeth without dental canals, not reaching trichobotrium $s b$; sensilla $p c$ well distad of $s b$; trichobothrium ist level with $e s b$ (ist slightly distal of $e s b$ ) and well proximad of lyrifissures $f b$; length of chela $0.58-0.61 \mathrm{~mm}$, length of movable chelal finger $0.34-0.36 \mathrm{~mm}$; chela $4.69-4.83$ times as long as deep; ratio of pedipalpal femur/carapace 1.20-1.21.

Description of adults $\left(+, \sigma^{7}\right)$. Small epigean species. Integument pigmented; marked hispid granulation on lateral surfaces of carapace, on cheliceral hand and on base of chelal fingers.

Carapace slightly longer than broad and weakly constricted posteriorly; anterior margin (Figs 4A-D) strongly 


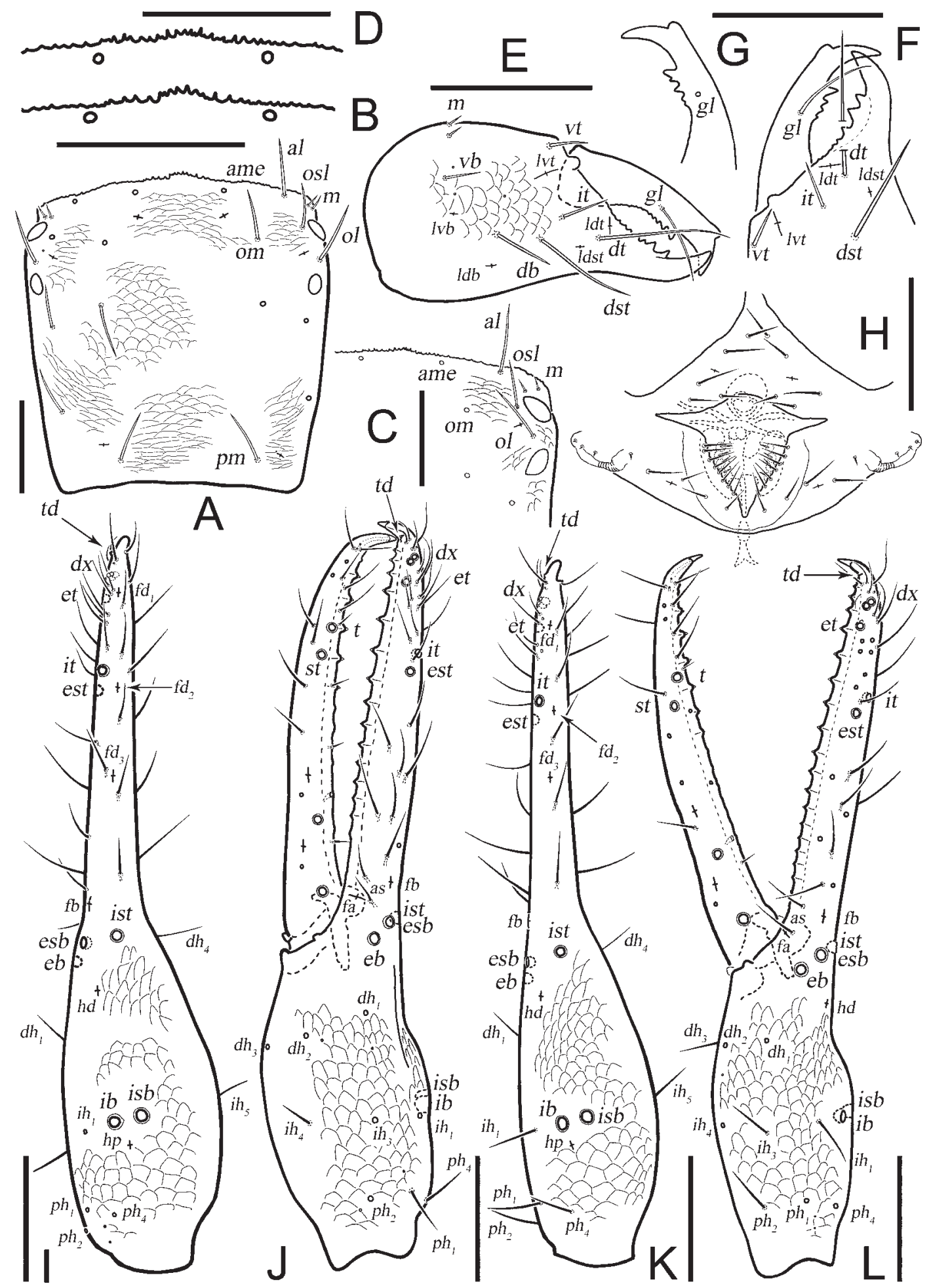

Fig. 4. Ephippiochthonius volkeri sp.n. 9 holotype and $\mathrm{O}^{7}$ paratype: A - holotype, carapace, dorsal view; B - holotype, anterior margin of carapace; $\mathrm{C}$ - paratype, anterolateral portion of carapace; D - paratype, anterior margin of carapace; E - holotype, left chelicera; F — paratype, left chelicera, partial view; $\mathrm{G}$ - paratype, movable finger of right chelicera, partial view; $\mathrm{H}$ — paratype, male genital area, genitalia are indicated by a dashed line; I — holotype, left chela, dorsal view; J - holotype, left chela, lateral view; K paratype, left chela, dorsal view; L — paratype, left chela, lateral view. Scale bars: $0.1 \mathrm{~mm}$.

Рис. 4. Ephippiochthonius volkeri sp.n. голотип и О паратип: А — голотип, карапакс, вид сверху; В — голотип, передний край карапакса; C - паратип, переднелатеральная часть карапакса; D - паратип, передний край карапакса; Е — голотип, левая хелицера; F — паратип, левая хелицера, часть; G — паратип, подвижный палец правой хелицеры, часть; Н — паратип, генитальная область самца, гениталии показаны пунктирной линией; I — голотип, левая хела, вид сверху; J — голотип, левая хела, вид сбоку; $\mathrm{K}$ - паратип, левая хела, вид сверху; L — паратип, левая хела, вид сбоку. Масштаб: 0,1 мм. 
dentate between median macrosetae, with short epistome; ocular area as in Figs 4A, C, anterior eyes with strongly convex lens (diameter $0.030-0.038 \mathrm{~mm}$ ), posterior eyes with flat lenses (diameter $0.030-0.036 \mathrm{~mm}$ ), all eyes with tapetum; distance from anterior eyes to anterior margin of carapace $0.030 \mathrm{~mm}$; the distance between the anterior and posterior eyes $0.030 \mathrm{~mm}$. Chaetotaxy: 18 macrosetae and 2 preocular microsetae $(\mathrm{m})$ on each side, posterior area with 2 medial macrosetae $(\mathrm{pm})$, posterolateral seta $(\mathrm{pl})$ absent, macrosetae thin; setal formula: $\mathrm{mm} 4 \mathrm{~mm}: 6: 4: 2: 2$, anterolateral setae $0.070 \mathrm{~mm}$ long, sublateral ocular setae $0.040-0.045$ $\mathrm{mm}$ long, lateral ocular setae $0.060 \mathrm{~mm}$ long; 4 lyrifissures anteriorly and 2 posteriorly.

Chaetotaxy of tergites: $4: 4: 4: 4: 6: 6: 6: 6: 1 \mathrm{~T} 2 \mathrm{~T} 1: 4: 1 \mathrm{~T} 2 \mathrm{~T} 1: 0$.

Chaetotaxy of sternites: + 10:(3)8(3):(2)7(2): $\mathrm{m} 6 \mathrm{~m}: \mathrm{m} 4 \mathrm{~m}$ : $\mathrm{m} 4 \mathrm{~m}: 6: 6: 2 \mathrm{~T} 1 \mathrm{~T} 2: 0: 2$, o $10:(3) 10(3):(2) 7(2): \mathrm{m} 6 \mathrm{~m}: \mathrm{m} 4 \mathrm{~m}:$ $\mathrm{m} 4 \mathrm{~m}: 6: 6: 2 \mathrm{~T} 1 \mathrm{~T} 2: 0: 2$, lateral setae on sternites III-VII microsetal in size, sternite $\mathrm{X}$ with 2 submedial tactile setae, genital notch of $\sigma^{7}$ (Fig. 4H) flanked by 7-8 setae on each side and $4+4$ internal glandular tubes.

Chelicera (Figs 4E-G) with 6 setae and 2 lateral microsetae; seta $v b 0.024-0.030 \mathrm{~mm}$ long, seta it $0.031-0.036$ $\mathrm{mm}$ long, seta $d b 0.050 \mathrm{~mm}$ long, seta $d s t 0.090 \mathrm{~mm}$ long, seta $d t 0.11 \mathrm{~mm}$ long, microsetae $0.014-0.020 \mathrm{~mm}$ long; all macrosetae are about the same thickness; hand with 5 dorsal and 1 ventral lyrifissure, lyrifissure $l d b$ present. Fixed finger with 5-6 teeth proximally reduced in size, two or three distal teeth larger than others; movable finger without an isolated subapical tooth $(d i)$, with $4-5$ teeth decreasing in size proximally, one or two distal teeth larger than others (sometimes two distal teeth are paired (Fig. 4G)); ratio seta $g l 0.60$; spinneret $(c s)$ prominent and apically rounded; rallum with 11 blades; serrulae interior and exterior respectively with 12 and 14 blades.

Coxal setae: pedipalpal coxa with 5 setae (including 2 on manducatory process), distal marginal seta of disk 0.08 mm long; coxa I $3+3$ marginal microsetae, distal marginal seta $0.061 \mathrm{~mm}$ long; II $4+6-7$ bipinnate coxal spines, III $5+$ 3 bipinnate coxal spines and IV 6; intercoxal tubercle bisetose.

Pedipalp: femoral chaetotaxy 3:6:2:5:1. Chela (Figs 4IL) with hand weakly depressed at level of $i b / i s b$ and an abrupt slope between trichobothria $i b / i s b$ and $e b$; intercondilar protuberance (ip) present; chaetotaxy 4:5:3; seta $p h_{3}$ lacking, setae $i h_{l}, i h_{3}$ and $i h_{4}$ approximately level with trichobothria $i b / i s b$. Fixed finger with 14-17 teeth, mostly pointed and with dental canals, decreasing in size proximally, 1 distal tooth is noticeably smaller than the second, dental row almost reaching distad of trichobothrium $b$ or a little shorter; base of fixed finger with 1-2 microtubercles; tip of fixed finger with a modified accessory tooth $(t d)$ on antiaxial face; one pair of long antiaxial sensory setae (as) at the finger base, distance between them shorter than finger depth at base; fixed chelal finger at level of est-it with 5-6 teeth occupying $0.1 \mathrm{~mm}$ (distance between successive apices $0.020-0.025 \mathrm{~mm}$ ). Tip of fixed chelal finger of male with a deep hollow on paraxial face and subapical protuberance $(s p)$. Distal half of movable chelal finger with 5-6 pointed teeth with dental canals, subdistal tooth very small, proximal half of dental lamina with 2-3 low vestigial teeth without dental canals, not reaching trichobotrium $s b$; basal apodeme long and apically indented; coupled sensilla $p c$ well distad of $s b$ in both sexes. Trichobothria as in Figs. 4I-L, trichobothrium ist level with esb (ist is slightly distal of $e s b$ ) and well proximad of lyrifissures $f b$; distance between $s t$ and $s b 2.10$ times longer than that between $s b$ and $b$. Chelal lyrifissure patterns $h p, h d, f b, f a_{1} f d_{1}, f d_{2}, f d_{3}, m a_{1}, m a_{2}$ present.

Measurements and ratios. ${ }^{3}$ holotype $\left(\sigma^{7}\right.$ paratype in square brackets): Body 1.19 [1.09]. Carapace 0.35/0.34 (1.01) [0.33/0.32 (1.01)]. Chelicera 0.30/0.15 (2.0) [0.27/0.13 (2.07)], movable finger 0.15 [0.13]. Pedipalp: femur $0.42 /$ 0.09 (4.66) [0.40/0.08 (5.0)], patella 0.19/0.10 (1.90) [0.17/ $0.09(1.88)]$, chela $0.61 / 0.13(4.69)[0.58 / 0.12(4.83)]$, hand $0.30[0.28]$, movable finger $0.36[0.34]$; ratio movable finger/hand 1.20 [1.21], femur/movable finger 1.16 [1.17], femur/carapace 1.20 [1.21], chela/carapace 1.74 [1.75], chela/femur 1.45 [1.45].

REMARKS. The new species is ascribed to the genus Ephippiochthonius on the basis of the following features: chela lagyniform (ephippiochthonian), seta $h p_{3}$ in the proximal portion of chelal hand absent, medial protuberance (ip) present between chelal condyles, tip of fixed chelal finger of male with a deep hollow on paraxial face and subapical protuberance $(s p)$. The new species belongs to the tetrachelatus-group as defined by Gardini [2013] and Zaragoza [2017] by having the chelal teeth of the fixed finger present nearly to the base of the finger, movable chelal finger with low, rounded, sometimes vestigial teeth, without a marginal lamina, intermediate paraxial setae $h i_{1}, h i_{3}$ and $h i_{4}$ of chelal hand level with trichobothria $i b / i s b$, chelal lyrifissure $m a$, present. Within the tetrachelatus-group, the new species is morphologically close to E. tetrachelatus (Preyssler, 1790). It differs from E. tetrachelatus in its smaller size, the position of the ist relative to the $i s b$, the coupled sensilla $p c$ well distad of $s b$ (in both sexes), and the presence of 2-3 low vestigial teeth on the proximal part of the movable chelal finger.

The epigean morphology of the described species found in Syundyurlyu-Kobasy (= Syundyurlyu) Cave indicates its possible trogloxene or at maximum subtroglophilic character. Most likely, this species is an inhabitant of the forest floor, and it got into the cave by accident, as it was found in the nearer (entrance) part of the cave, in the zone where sunlight penetrates (see Fig. 1B). To clarify this assumption, it is necessary to collect forest litter and soil on the surface near the cave.

\section{Ephippiochthonius pliginskyi sp.n. Fig. 5.}

Obisium abeillei (Simon) - Lebedinsky, 1904: 80, 86, fig. 24; Pliginsky, 1927: 172; Turbanov, Kolesnikov, 2015: 83; Turbanov et al., 2016: 1286.

Chthonius tetrachelatus (Preyssler) — Pliginsky, 1927: 172; Turbanov, Kolesnikov, 2015: 83; Turbanov et al., 2016: 12851286.

HOLOTYPE $\sigma^{7}$ (ZISP 382) Crimean Peninsula, Simferopol Dist., env. of Perevalnoye Vill., W slope of Dolgorukovskaya Yaila, Kizil-Koba (= Krasnaya) Cave, 7 June 1913, leg. V.G. Pliginsky.

DISTRIBUTION. Known from the type locality so far.

NAME. Named after Vladimir G. Pliginsky (1884-?) a Russian and Soviet entomologist, the pioneer of biospeleological researchers in the caves of the Crimea; the collector of the described new species.

DIAGNOSIS ( $\sigma^{7}$, + unknown). A large hypogean Ephippiochthonius that differs from other species of the tetrachelatus-group with the following combination of characters: anterior eyes with convex lens, posterior eyes reduced to a smooth cuticular area; movable cheliceral finger without a small isolated subapical tooth (di); spinneret (cs) almost absent in male; carapace without the epistome; anterolateral setae 1.4 times longer than sublateral ocular setae; postero- 


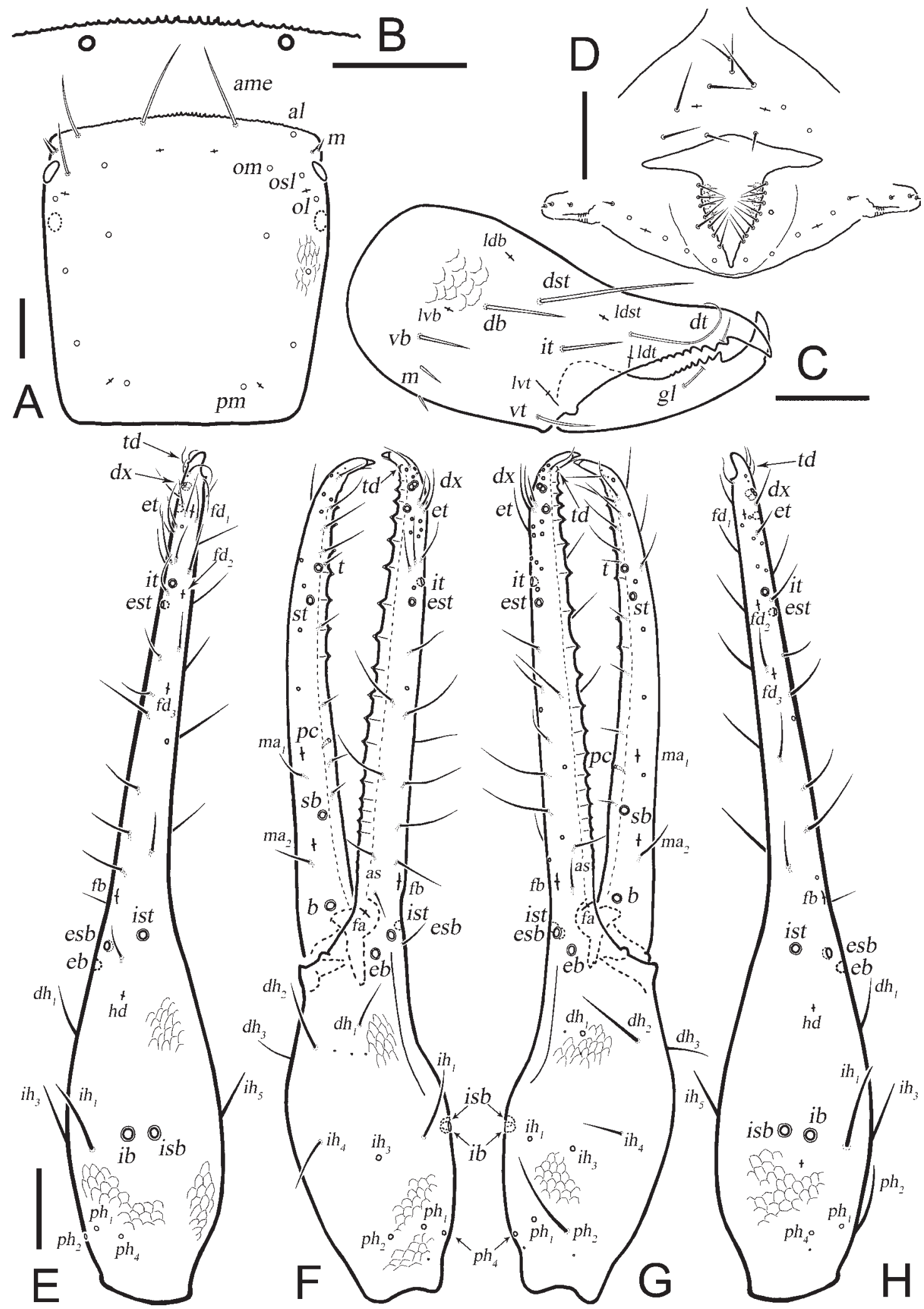

Fig. 5. Ephippiochthonius pliginskyi sp.n. $\sigma^{7}$ holotype: A — carapace, dorsal view; B - anterior margin of carapace; C - right chelicera; D - male genital area; E — left chela, dorsal view; F — left chela, lateral view; G — right chela, lateral view; H - right chela, dorsal view. Scale bars: $0.1 \mathrm{~mm}$.

Pис. 5. Ephippiochthonius pliginskyi sp.n. О7 голотип: А - панцирь, вид сверху; В - передний край карапакса; C — правая хелицера; D — генитальная область самца; Е — левая хела, вид сверху; F — левая хела, вид сбоку; $\mathrm{G}$ — правая хела, вид сбоку; Н правая хела, вид сверху. Масштаб: 0,1 мм. 
lateral seta $(p l)$ of carapace absent; pedipalpal hand (in lateral view) with weak depression at the level of $i b / i s b$ and an abrupt slope between trichobothria $i b / i s b$ and $e b$; fixed and movable chelal fingers respectively with $17-18$ and 6-7 triangular teeth; fixed chelal finger at level of est-it with 3 teeth occupying $0.1 \mathrm{~mm}$ (distance between successive apices $0.045 \mathrm{~mm}$ ); proximal half of movable chelal finger smooth, without dental canals; sensilla $p c$ well distad of $s b$; trichobothrium ist level with esb (ist is slightly distal of esb) and well proximad of lyrifissures $f b$; length of chela $1.07 \mathrm{~mm}$, length of movable chelal finger $0.66 \mathrm{~mm}$; chela 5.35 times as long as deep; ratio of pedipalpal femur/carapace 1.45.

Description of adults $\left(\sigma^{\gamma},+\right.$ unknown). Large, hypogean, moderately troglomorphic species. Integument depigmented; weakly hispid granulation on lateral surfaces of carapace, carapace, on cheliceral hand on base of chelal fingers.

Carapace slightly longer than broad and weakly constricted posteriorly; anterior margin (Figs 5A, B) closely dentate between median macrosetae, without epistome; ocular area as in Figs 5A, anterior eyes with convex lens (diameter $0.040 \mathrm{~mm}$ ), posterior eyes reduced to a smooth cuticular area (diameter $0.030 \mathrm{~mm}$ ), all eyes with tapetum; distance from anterior eyes to anterior margin of carapace $0.050 \mathrm{~mm}$; the distance between the anterior and posterior eyes 0.050 $\mathrm{mm}$. Chaetotaxy: 18 macrosetae and 2 preocular microsetae $(m)$ on each side, posterior area with 2 medial macrosetae $(p m)$, posterolateral seta $(p l)$ absent, macrosetae thin; setal formula: $\mathrm{mm} 4 \mathrm{~mm}: 6: 4: 2: 2$, anteromedial setae $0.13 \mathrm{~mm}$ long, anterolateral setae $0.11 \mathrm{~mm}$ long, sublateral ocular setae $0.08 \mathrm{~mm}$ long; 4 lyrifissures anteriorly and 2 posteriorly.

Chaetotaxy of tergites: 4:4:4:4:6:6:6:6:1T2T1:4:1T2T1:0.

Chaetotaxy of sternites: 10:(3)10(3):(2)7(2):m6m: m6m:m5m:6:6:2T1T2:0:2, lateral setae on sternites III-VII microsetal in size, sternite $\mathrm{X}$ with 2 submedial tactile setae, genital notch of $\sigma^{7}$ (Fig. 5D) flanked by $8-9$ setae on each side and $4+4$ internal glandular tubes.

Chelicera (Figs 5C) with 6 setae and 2 lateral microsetae on hand; seta $v b 0.060 \mathrm{~mm}$ long, seta it $0.065 \mathrm{~mm}$ long, seta $d b 0.080 \mathrm{~mm}$ long, seta $d s t 0.184 \mathrm{~mm}$ long, seta $d t 0.160$ $\mathrm{mm}$ long, microsetae $0.020 \mathrm{~mm}$ long; all macrosetae are about the same thickness; hand with 5 dorsal and 1 ventral lyrifissure, lyrifissure $l d b$ present. Fixed finger with 8 teeth proximally reduced in size, three distal teeth larger than others; movable finger without an isolated subapical tooth (di), with 8 teeth decreasing in size proximally, four distal teeth larger than others; ratio seta $g l 0.55$; spinneret $(c s)$ almost absent in male (Fig. 5C); rallum with 11-12 blades; serrulae interior and exterior respectively with 11 and 12 blades.

Coxal setae: pedipalpal coxa with 5 setae (including 2 on manducatory process), distal marginal seta of disk 0.14 mm long; coxa I $3+3$ marginal microsetae, distal marginal seta $0.07 \mathrm{~mm}$ long; II $4+8-10$ bipinnate coxal spines, III 6 + 6-7 bipinnate coxal spines and IV 6; intercoxal tubercle bisetose.

Pedipalp: femoral chaetotaxy 3:6:2:5:1. Chela (Figs 5E$\mathrm{H})$ with hand weakly depressed at level of $i b / i s b$ and an abrupt slope between trichobothria $i b / i s b$ and $e b$; intercondilar protuberance (ip) present; chaetotaxy 4:5:3; seta $p h_{3}$ lacking, setae $i h_{1}, i h_{3}$ and $i h_{4}$ approximately level with trichobothria $i b / i s b$. Fixed finger with 17-18 teeth, mostly pointed and with dental canals, decreasing in size proximally, 1 distal tooth is noticeably smaller than the second, dental row reaching slightly proximally of trichobothrium $s b$; base of fixed finger with 3-4 microtubercles; tip of fixed finger with a modified accessory tooth $(t d)$ on antiaxial face; one pair of long antiaxial sensory setae (as) at the finger base, distance between them shorter than finger depth at base; fixed chelal finger at level of est-it with 3 teeth occupying $0.1 \mathrm{~mm}$ (distance between successive apices 0.045 $\mathrm{mm}$ ). Tip of fixed chelal finger of male with a deep hollow on paraxial face and subapical protuberance $(s p)$. Distal half of movable chelal finger with 6-7 pointed teeth with dental canals, subdistal tooth absent, proximal half of dental lamina smooth, without dental canals, dental row not reaching halfway between trichobothria $s t$ and $s b$; basal apodeme long and apically indented; coupled sensilla $p c$ well distad of $s b$. Trichobothria as in Figs. 5E-H, trichobothrium ist level with esb (ist is slightly distal of $e s b$ ) and well proximad of lyrifissures $f b$; distance between $s t$ and $s b 2.20$ times longer than that between $s b$ and $b$. Chelal lyrifissure patterns $h p, h d, f b, f a, f d_{1}, f d_{2}, f d_{3}, m a_{1}, m a_{2}$ present.

Measurements and ratios. $\sigma^{7}$ holotype: Body 2.0. Carapace 0.51/0.49 (1.04). Chelicera 0.46/0.20 (2.3), movable finger 0.23 . Pedipalp: femur $0.74 / 0.11$ (6.70), patella $0.31 /$ 0.14 (2.20), chela $1.07 / 0.20(5.35)$, hand 0.49 , movable finger 0.66 ; ratio movable finger/hand 1.35 , femur/movable finger 1.12 , femur/carapace 1.45 , chela/carapace 2.09 , chela/femur 1.45 .

REMARKS. The new species is described to the genus Ephippiochthonius on the basis of the following features: chela lagyniform (ephippiochthonian), setae $h p 3$ in the proximal portion of chelal hand absent, medial protuberance (ip) present between chelal condyles, tip of fixed chelal finger of male with a deep hollow on paraxial face and subapical protuberance $(s p)$. The new species belongs to the tetrachelatus-group as defined by Gardini [2013] and Zaragoza [2017] by having the chelal teeth of the fixed finger present nearly to the base of the finger, the movable chelal finger with low, rounded, sometimes vestigial teeth, without a marginal lamina, intermediate paraxial setae hil, hi3 and hi4 of chelal hand level with trichobothria $i b / i s b$, chelal lyrifissure $m a 2$ present. Within the tetrachelatus-group, the new species is morphologically close E. tauroscythicus sp.n. and E. concii from Italy. The new species differs from E. tauroscythicus sp.n. in a slightly smaller size of chela and pedipalpal femur, smaller ratios of pedipalpal femur/carapace and chela/carapace, a smaller number of teeth on the movable and fixed chelal fingers, a larger distance between $s t$ and $s b$ relative to the distance between $s b$ and $b$, the location of ist relative to $e s b$ (ist is slightly distal of esb), the teeth of the movable chelal finger are far from reaching the middle of the distance between $s b$-st, a smaller distance between sensory setae (as) relative to the depth of the fixed finger. From E. concii it differs in a smooth part of lamina basalis on movable chelal finger, distal location coupled sensilla $p c$ regarding $s b$, a large distance between the abterior and podterior eyes, a smaller distance between the sensory setae (as).

The specimen, on the basis of which the species is described, was previously identified by V.V. Redikorzev as Chthonius tetrachelatus (Preyssler, 1790) $(=$ E. tetrachelatus) [see Pliginsky, 1927]. However, there is no doubt that this species belongs to the tetrachelatus-group, but not to species of E. tetrachelatus sensu Gardini [2009], as indicated by a number of features: size and proportions, the structure of the ocular area, chelicera and chela. Earlier, from the same cave - Kizil-Koba (= Krasnaya), O. abeillei was quoted [Lebedinsky, 1904], assigned by V.V. Redikorzev to Ch. tetrachelatus [Pliginsky, 1927]. At the moment, this specimen is untraceable, but according to J. Lebedinsky's 
[1904, see fig. 24] we can conclude that quotations of $O$. abeillei and C. tetrachelatus, respectively by Lebedinsky [1904] and Pliginsky [1927] must be referred to E. pliginskyi sp.n.

\section{Discussion}

For the described species of the genus Ephippiochthonius from the Crimea, the distal location of coupled sensilla $p c$ relative to trichobothria $s b$ was observed. In his key, Zaragoza [2017] indicates the location of the $p c$ relative to the $s b$ as a supraspecific feature for taxonomy. Gardini [2008, 2013] notes intraspecific variation position bristles for some species (eg, E. gestroi (Simon, 1896), E. troglophilus (Beier, 1930), E. zoiai (Gardini, 1990) and E. siculus (Beier, 1961)), however, in these cases the $p c$ does not go beyond the $s b$ (the exception is E. siculus, in females the $p c$ is slightly distal than the $s b$ ). In E. pliginskyi sp.n. described by us, the distance between $s b$ and $p c$ on the left and right chelas of one instance may vary within $0.06-0.1 \mathrm{~mm}$, but the $p c$ on both chelas is located more distal than $s b$. In our opinion, it is worth paying attention to the position of the $p c$ relative to the $s b$ when determining the characteristics of the species; however, more material is needed for a better understanding of the taxonomic meaning of this character.

E. tauroscythicus sp.n. and E. pliginskyi sp.n. have a morphology close to troglomorphic: large body size (1.97 and 2.0, respectively), long pedipalp femur (ratio femur/carapace 1.53-1.61 and 1.45, respectively), long hela (ratio chela/carapace 2.32-2.38 and 2.09, respectively), long helal finger (ratio movable finger/hand $1.30-1.36$ and 1.35 , respectively), reduced posterior eyes. At the same time, both of these species have welldeveloped anterior eyes. These species can be considered as neotroglobionts that settled hypogean biotopes on the territory of the Crimean Peninsula in the Late Pleistocene due to global climatic changes, i.e. the alternation of glacial and interglacial periods [Jeannel, 1959; Vandel, 1964]. According to our earlier studies [Prokopov, Turbanov, 2017], the most intense evolution of the Crimean troglobiont fauna occurred in the Middle and Late Pleistocene. Most likely, the ancestral land (soil) form of these species lived on the territory of the Mountainous Crimea in the Riss-Würm interglacial period, and the beginning of the Würm glacial periods provoked the development of hypogean biotopes. Later, taking into account the population isolation, allopatric speciation occurred; however, to confirm this hypothesis, it is necessary to carry out a specific research of these species using molecular genetic analysis in the future. A similar Late Pleistocene speciation scenario was described for troglobiont false scorpions of the genus Pseudoblothrus Beier, 1931, inhabiting the caves in the Crimean Mountains [Turbanov, Kolesnikov, 2020]. The third described species, $E$. volkeri sp.n., as mentioned above, clearly has an epigean morphology and is most likely a trogloxene or subtroglophile.
Thus, the obtained results significantly supplement the available data on hypogean fauna and expand the knowledge about the false scorpions of the Crimea as a region of the Eastern Mediterranean with a rich biodiversity.

Acknowledgments. Our deep gratitude goes to Kirill G. Mikhailov (ZMUM, Moscow) and Viktor A. Krivokhatsky (ZISP, Saint Petersburg) for possibility deposited and study types materials in the museum collections under their care. We thank Natalia V. Ashchepkova (Civo SO, Italy) for improving the English language of the manuscript. Thanks are also due to Giulio Gardini (University of Genoa, Italy) and Srećko Ćurčić (University of Belgrade, Serbia) for bibliographic assistance. We express our gratitude to the reviewers, G. Gardini and Alexander G. Koval (All-Russian Institute of Plant Protection (VIZR), Saint Petersburg Pushkin), for valuable remarks and comments that significantly improved this publication. A special thank to our crimean friends, speleologists Sergey V. Arefyev and Sergey N. Bagach (Sevastopol) for providing fotos of the cave biotopes. This study by Ilya S. Turbanov was performed in the framework of the state assignment (topics No. ÀÀÀiÀ18-118012690105-0, ÀÀÀÀ-À18-118012690106-7).

\section{References}

Chamberlin J.C. 1931. The arachnid order Chelonethida. Stanford University Publications, University Series (Biol. Sci.). Vol.7. P.1-284.

Chamberlin J.C. 1949. New and little-known false scorpions from various parts of the world (Arachnida, Chelonethida), with notes on structural abnormalities in two species // American Museum Novitates. Vol.1430. P.1-57.

Ćurčić B.P.M. 1984. The genus Neobisium Chamberlin 1930 (Neobisiidae, Pseudoscorpiones, Arachnida): on new species from the USSR and the taxonomy of its subgenera // Bulletin du Muse'um National d'Histoire Naturelle. Belgrade (Section B). Vol.39. P.123-153.

Dashdamirov S. 1999. New records of false scorpions in the Caucasus (Arachnida: Pseudoscorpiones) // Arthropoda Selecta. Vol.8. No.2. P.79-87.

Dashdamirov S., Schawaller W. 1993. [Pseudoscorpions of the Caucasian fauna (Arachnida Pseudoscorpionida)] // Arthropoda Selecta. Vol.1 (for 1992). No.4. P.31-72 [in Russian, with notes in English].

Ellingsen E. 1910. Pseudoskorpione und Myriopoden des Naturhistorischen Museums der Stadt Wiesbaden // Jahrbücher des Nassauischen Vereins für Naturkunde. Bd.63. S.62-65 [in German].

Gabbutt P.D., Vachon M. 1963. The external morphology and life history of the pseudoscorpion Chthonius ischnocheles (Hermann) // Proceedings of the Zoological Society of London. Vol.140. P.75-98. https://doi.org/10.1111/j.1469-7998.1963. tb01855.x

Gardini G. 2008. Pseudoscorpioni d'Italia XLII. Chthoniidae cavernicoli di Sardegna (Pseudoscorpiones) // Memorie della Società Entomologica Italiana. Vol.87. P.3-31. https://doi.org/ 10.4081/memorieSEI.2008.3

Gardini G. 2013. A revision of the species of the pseudoscorpion subgenus Chthonius (Ephippiochthonius) (Arachnida, Pseudoscorpiones, Chthoniidae) from Italy and neighbouring areas // Zootaxa. Vol.3655. No.1. P.1-151. http://dx.doi.org/10. 11646/zootaxa.3655.1.1

Gardini G. 2014. The species of the Chthonius heterodactylus group (Arachnida, Pseudoscorpiones, Chthoniidae) from the eastern Alps and the Carpathians // Zootaxa. Vol.3887. No.2. P.101-137. https://doi.org/10.11646/zootaxa.3887.2.1 
Harvey M.S. 1992. The phylogeny and classification of the Pseudoscorpionida (Chelicerata: Arachnida) // Invertebrate Taxonomy. Vol.6. P.1373-1435. https://doi.org/10.1071/IT9921373

Jeannel R. 1959. Situation geographique et peuplement des caverns // Annales de spéléologie. T.14. P.333-338.

Judson M.L.I. 2007. A new and endangered species of the pseudoscorpion genus Lagynochthonius from a cave in Vietnam, with notes on chelal morphology and the composition of the Tyrannochthoniini (Arachnida, Chelonethi, Chthoniidae) // Zootaxa Vol.1627. No.1. P.53-68. http://dx.doi.org/10.11646/zootaxa.1627.1.4

Kolesnikov V.B., Turbanov I.S. 2017. [To the knowledge of troglobiont pseudoscorpions of the genus Pseudoblothrus Beier, 1931 (Arachnida: Pseudoscorpiones: Syarinidae) in the Crimean Peninsula] // Materialy II Vserossiyskoy molodezhnoy konferentsii 'Biospeleologicheskie issledovaniya v Rossii i sopredelnykh gosudarstvakh. Moscow, December 1-2, 2017. Yaroslavl: Filigran. P.50-55 [in Russian, with English summary].

Kolesnikov V.B., Turbanov I.S. 2018. The cave-dwelling false scorpion genus Pseudoblothrus Beier, 1931 (Arachnida: Pseudoscorpiones: Syarinidae) in the Crimean Peninsula // Zootaxa. Vol.4374. P.4. P.524-544. https://doi.org/10.11646/zootaxa.4374.4.4

Kolesnikov V.B., Turbanov I.S., Gongalsky K.B. 2019. Two new species false scorpion genus Ephippiochthonius Beier, 1930 (Arachnida: Pseudoscorpiones: Chthoniidae) from the Western Ciscaucasia, Russia // Arthropoda Selecta. Vol.28. No.1. P.7382. https://doi.org/10.15298/arthsel.28.1.06

Lebedev N.D. 1914. [Caves of Crimea and their Fauna] // Zapiski Krymsko-Kavkazskogo gornogo kluba. Vol.2. No.2. P.3-28 [in Russian].

Lebedev N.D. 1927. [New caves in the Crimea] // Krym. No.2(4). P.42-49 [in Russian].

Lebedinsky Ya. 1904. [Zur Höhlenfauna der Krym (continuation)] // Zapiski Novorossiyskogo îbshchestva estvoispytateley. Vol.25. No.2. S.75-88. 2 pls. [In Russian]

Mahnert V. 2011. New records of pseudoscorpions from the Juan Fernandez Islands (Chile), with the description of a new genus and three new species of Chernetidae (Arachnida: Pseudoscorpiones) // Revue Suisse de Zoologie. T.118. P.17-29. https:// doi.org/10.5962/bhl.part.117795

Nassirkhani M., Snegovaya N., Chumachenko Y.A. 2019. Description of a new epigean species of the genus Ephippiochthonius (Pseudoscorpiones: Chthoniidae) from Russia // Acta Arachnologica. Vol.68. No.1. P.1-5. https://doi.org/10.2476/asjaa.68.1

Pliginsky V.G. 1927. [On the fauna of Crimean caves. Communication 3] // Russkoye entomologicheskoe obozrenie. Vol.21. No.3-4. P.171-18 [in Russian].

Prokopov G.A., Turbanov I.S. 2017. [To the question of speleofauna formation in the Crimean Peninsula] // Materialy II Vse- rossiyskoy molodezhnoy konferentsii 'Biospeleologicheskie issledovaniya v Rossii i sopredelnykh gosudarstvakh. Moscow, December 1-2, 2017. Yaroslavl: Filigran. P.99-106 [in Russian, with English summary].

Redikorzev V. 1918. Pseudoscorpions nouveaux. I // Ezhegodnik Zoologicheskogo muzeya Rossiyskoy akademii nauk. Vol.22. P.91-101.

Schawaller W. 1983. Pseudoskorpione aus dem Kaukasus (Arachnida) // Stuttgarter Beiträge zur Naturkunde. Serie A (Biologie). No.362. S.1-24.

Schawaller W. 1989. Pseudoskorpione aus der Sowjetunion, Teil 3 (Arachnida: Pseudoscorpiones) // Stuttgarter Beiträge zur Naturkunde. Serie A (Biologie). No.440. S.1-30.

Schawaller W. Dashdamirov S. 1988. Pseudoskorpione aus dem Kaukasus, Teil 2 (Arachnida) // Stuttgarter Beiträge zur Naturkunde. Serie A (Biologie). No.415. S.1-51.

Turbanov I.S., Kolesnikov V.B. 2015. [A review of cave false scorpions (Arachnida: Pseudoscorpiones) of Crimea and the Caucasus] // Materialy I Vserossiyskoy molodezhnoy konferentsii 'Biospeleologiya Kavkaza i drugikh rayonov Rossii'. Moscow, December 3-5, 2015. Yaroslavl: Filigran. P.80-86 [in Russian, with English summary].

Turbanov I.S., Kolesnikov V.B. 2020. Two new cave-dwelling species of the false scorpion genus Pseudoblothrus Beier, 1931 (Arachnida: Pseudoscorpiones: Syarinidae) from the Crimean Peninsula // Arthropoda Selecta. Vol.29. No.1. P.28-50. http:// dx.doi.org/10.15298/arthsel. 29.1.03

Turbanov I.S., Palatov D.M., Golovatch S.I. 2016. [The state of the art of biospeleology in Russia and other countries of the former Soviet Union: a review of cave (endogean) invertebrate fauna. 2. Arachnida - Acknowledgements] // Zoologicheskii Zhurnal. Vol.95. No.11. P.1283-1304 [in Russian; English translation: Entomological Review. 2016. Vol.96. No.9. P.1297-1333] http://dx.doi.org/10.7868/S0044513416110064

Vandel A. 1964. Biospéologie. La Biologie des Animaux Cavernicoles. Paris: Gauthier-Villars. 679 pp.

Zaragoza J.A. 2010. Arcanobisium, a remarkable new genus, representing a new subfamily with a relictual distribution from eastern Spain (Arachnida: Pseudoscorpiones: Syarinidae) // Zootaxa. Vol.2491. No.1. P.41-60. http://dx.doi.org/10.11646/ zootaxa.2491.1.3

Zaragoza J.A. 2017. Revision of Ephippiochthonius complex in the Iberian Peninsula, Balearic Islands and Macaronesia, with proposed changes to the status of Chthonius subgenera (Pseudoscorpiones, Chthoniidae) // Zootaxa. Vol.4246. No.1. P.1221. https://doi.org/10.11646/zootaxa.4246.1.1

Responsible editor K.G. Mikhailov 